\title{
SELECTIVE ANTICANCER ACTIVITY OF CURCUMA XANTHORRHIZA FERMENTED JUICE
}

\author{
WARINTORN RUKSIRIWANICH ${ }^{1 *}$, HIROYUKI AKAZAWA ${ }^{2}$, PENSAK JANTRAWUT ${ }^{1}$
}

${ }^{1}$ Pharmaceutical and Natural Products Research and Development Unit, Department of Pharmaceutical Sciences, Faculty of Pharmacy, Chiang Mai 50200, Thailand. 2Department of Biotechnology and Material Chemistry, Nihon University Junior College, 7-24-1, Narashinodai, Funabashi-shi, Chiba 274-8501, Japan. Email: warintorn.ruksiri@hotmail.com

\author{
Received: 28 March 2018, Revised and Accepted: 10 May 2018
}

ABSTRACT

Objective: The objective of this study was to investigate the anticancer activity and toxicity of fermented juices from six Thai plants, Garcinia mangostana Linn., Tinospora crispa Linn., Litchi chinensis Sonn., Dimocarpus longan Lour., Curcuma xanthorrhiza (CX) Roxb., and Averrhoa bilimbi Linn., in cancer cell lines and normal cells as compared with common commercial fermented juices.

Methods: The plants were fermented for 3 months, and their biological activities including 2,2-diphenyl-1-picrylhydrazyl radical (DPPH) scavenging, metal chelating, lipid peroxidation inhibition, and tyrosinase inhibition activities were subsequently evaluated. Furthermore, their in vitro anticancer activities in human colon adenocarcinoma (HT-29), cervical cancer (HeLa), hepatocellular carcinoma (HepG2), and murine melanoma (B16F10) cell lines and their toxicities in normal human skin fibroblasts were assessed.

Results: The fermented juice of CX showed a higher antioxidant activity than those of the other plants, with an $\mathrm{SC}_{50}$ (DPPH scavenging) value of $0.011 \mathrm{mg} / \mathrm{mL}$, an $\mathrm{IPC}_{50}$ (lipid peroxidation inhibition) of $0.027 \mathrm{mg} / \mathrm{mL}$, an $\mathrm{MC}_{50}$ (metal chelating) value of $0.170 \mathrm{mg} / \mathrm{mL}$, and an IC ${ }_{50}$ (tyrosinase inhibition) of $0.027 \mathrm{mg} / \mathrm{mL}$. Moreover, the fermented juice of CX displayed selective toxicity in cancer cell lines (HeLa, HepG2, and B16F10), with a significantly lower toxicity in normal human skin fibroblasts as compared with an expensive commercial fermented juice product.

Conclusion: The present study suggests that the fermented juice of CX can be developed as a functional food supplement with antioxidant properties or as an anticancer product with low toxicity to normal human skin fibroblasts.

Keywords: Fermented juice, Curcuma xanthorrhiza, Anticancer, HeLa, HT-29, HepG2, B16F10.

(C) 2018 The Authors. Published by Innovare Academic Sciences Pvt Ltd. This is an open access article under the CC BY license (http://creativecommons. org/licenses/by/4. 0/) DOI: http://dx.doi.org/10.22159/ajpcr.2018.v11i8.26303

\section{INTRODUCTION}

Fermentation is a cheap and energy efficient means of preserving perishable raw materials. When fruit and vegetables are harvested, they undergo rapid deterioration, especially in the humid tropics where the prevailing environmental conditions accelerate the process of decomposition [1]. Fermentation requires very little sophisticated equipment for either the fermentation process or for subsequent storage of the fermented product [2]. It is a technique that has been employed for generations to preserve food for consumption at a later date and to improve food security $[3,4]$.

Molasses is an agro-industrial by-product of the processing of sugarcane and sugar beet into sugar. It is often used as a microbiological energy source in a wide range of fermentation processes to grow yeasts, molds, and bacteria that transform sugars into alcohol, yeast, citric acid, and the food additives monosodium glutamate and lysine. Molasses is the most cost-effective of the main energy sources available for such industries, is easy to incorporate into fermentation processes, and represents a stable and predictable substrate for storage and handling [5]. The development of foods and beverages that promote health and well-being is one of the current research priorities. The trend of consumption of food enriched in probiotics is increasing due to scientific evidence that they help to maintain healthy gut microflora [6,7]. It has been suggested that fruit or vegetable juices could serve as a suitable media for cultivating probiotic bacteria [8]. Various studies have been carried out to explore the suitability of fermented fruit or vegetable juices such as tomato, beetroot, and cabbage as raw materials for the production of fermented drinks.
Many medicinal plants have shown antioxidant and other applications to promote vitality and well-being. Garcinia mangostana (GM) (Clusiaceae), commonly known as mangosteen, is a slow-growing tropical evergreen tree found mainly in India, Myanmar, Sri Lanka, and Thailand. Recently, products manufactured from GM have begun to be used as botanical dietary supplements in the United States due to their potent antioxidant potential [9]. Moreover, GM, ethyl acetate extract was reported to have cytotoxic effect on T47D breast cancer cell line [10]. Tinospora crispa (TC) (Menispermaceae) is an herbaceous climbing plant that is widely distributed in Southeast Asia, particularly in Vietnam, Thailand, and Malaysia [11]. Oral administration of the stem decoction of this medicinal herb has been used in traditional Thai medicine due to its antipyretic, antidiabetic, anti-inflammatory, antioxidant, and health-maintaining properties [12-14]. Lychee (Litchi chinensis [LC]) and Longan (Dimocarpus longan [DL]) are members of the Sapindaceae family, which are highly attractive subtropical fruits widely distributed in Northern Thailand. These fruits are well received by consumers due to their delicious taste and possible health benefits. They contain significant amounts of phenolic compounds that have been confirmed to have antioxidant and anticancer activities [15-18]. Curcuma xanthorrhiza (CX), a member of the Zingiberaceae family and a native Indonesian plant, is grown in Thailand, the Philippines, Sri Lanka, and Malaysia. CX is a low-growing plant with a rhizome similar to ginger and has an aromatic, pungent odor, and bitter taste [19] with antibacterial activity [20]. Averrhoa bilimbi (AB), also called Bilimbi, is found throughout Indonesia, the Philippines, Bangladesh, and other Southeastern Asian countries. Bilimbi has been used in traditional medicine to control obesity and diabetes mellitus [21] and also possesses antihyperlipidemic properties [22]. Moreover, some Thais believe that the fermented juice of these six plants or expensive 
commercial fermented juice $(10 \mathrm{USD} / \mathrm{mL})$ can be used as anticancer remedies by drinking once daily. However, there exists no scientific evidence of the anticancer activities or the safety profiles in normal cells of the fermented juices of these six plants.

In the present study, these six plants were fermented for 3 months, and their biological activities including 2,2-diphenyl-1-picrylhydrazyl radical (DPPH) scavenging, metal chelating, lipid peroxidation inhibition, and tyrosinase inhibition were evaluated. Furthermore, their in vitro anticancer activities in HeLa, HT-29, HepG2, and B16F10 cell lines and their toxicity in normal cells were assessed.

\section{MATERIALS AND METHODS}

\section{Materials}

Ascorbic acid, $\alpha$-tocopherol, DPPH, ammonium thiocyanate $\left(\mathrm{NH}_{4} \mathrm{SCN}\right)$, ethylenediaminetetraacetic acid (EDTA), ferrozine, ferric chloride $\left(\mathrm{FeCl}_{2}\right)$, potassium persulfate, linoleic acid, sulfurhodamine B (SRB), tris(hydroxymethyl)-methylamine, and trichloroacetic acid (TCA) were purchased from Sigma Chemical Co. (St. Louis, MO, USA). Tyrosinase from mushroom $(4187 \mathrm{U} / \mathrm{mg})$ and L-tyrosine were purchased from Fluka (Switzerland). Dulbecco's modified Eagle's medium (DMEM), $\alpha$-modified Eagle's culture medium (MEM-alpha), fetal bovine serum (FBS), penicillin, and streptomycin were obtained from GIBCO (Grand Island, NY, USA). Absolute ethanol was purchased from Fisher Scientific (Fair Lawn, NJ). All other chemicals and reagents were of analytical grade.

\section{Plant selection}

Six medicinal plants, GM, TC, LC, DL, CX, and AB, which have scientific evidence of antioxidant activity, were selected. These plants were collected from Chiang Mai Province in Thailand during JanuaryFebruary 2014 (Table 1). The specimens were authenticated by a botanist and deposited at the Faculty of Pharmacy, Chiang Mai University, Thailand.

\section{Preparation of fermented juices}

The six plants were washed, cut into pieces, and air-dried. For the fermentation process of CX and TC, each plant was mixed with water (reverse osmosis) and molasses in a 1:10:1 weight ratio, while a ratio of 3:10:1 was used for the other plants (GM, LC, DL, and AB). The fermented juices were sampled at $0,1,2$, and 3 months for antioxidant and tyrosinase inhibition activity determination.

\section{Antioxidant assays}

\section{DPPH radical sc avenging activity}

The DPPH radical scavenging activities of the fermented juices were determined using a previously described method [23], with slight modifications. Briefly, five serially diluted concentrations of each sample, along with $50 \mu \mathrm{L}$ distilled water and $50 \mu \mathrm{L}$ ethanolic solution of DPPH, were added to the wells of a 24-well plate (Nalge Nunc International, NY, USA). The reaction mixture was allowed to incubate for $30 \mathrm{~min}$ at $25 \pm 2^{\circ} \mathrm{C}$, after which the solution was separated, transferred to a 96-well microplate, and the absorbance was measured at $515 \mathrm{~nm}$ against a blank (ethanol) using a plate reader (Bio-Rad, model 680 microplate reader, USA). Ascorbic acid was used as the positive control. All experiments were performed in triplicate. The percentages of DPPH radical scavenging activity were calculated using the following equation:
DPPH scavenging activity $(\%)=\frac{A_{\text {control }}-A_{\text {sample }}}{A_{\text {control }}} \times 100 \%$

Where, $A_{\text {sample }}$ is the absorbance of the DPPH radical with the extract and $A_{\text {control }}$ is the absorbance of the DPPH radical alone. The $\mathrm{SC}_{50}$ value, which is the concentration of the sample that scavenged $50 \%$ of the DPPH radical, was determined. A histogram of the DPPH scavenging activity (\%) of $0.01 \mathrm{mg} / \mathrm{mL}$ samples following $0,1,2$, and 3 months fermentation is presented.

\section{Lipid peroxidase inhibition activity}

The lipid peroxidase inhibition activities of the fermented juices were assayed using a modified ferric thiocyanate method [24,25]. Five serially diluted concentrations of each sample, $100 \mu \mathrm{L}$ distilled water and $50 \mu \mathrm{L}$ linoleic acid in 50\% (v/v) DMSO, were added to a 24-well plate. The reaction was initiated by the addition of $50 \mu \mathrm{L} \mathrm{NH}_{4} \mathrm{SCN}(5$ $\mathrm{mM}$ ) and $50 \mu \mathrm{L} \mathrm{FeCl} 22 \mathrm{mM}$ ). The mixture was incubated at $37 \pm 2^{\circ} \mathrm{C}$ for $1 \mathrm{~h}$. During the oxidation of linoleic acid, peroxides are formed that lead to the oxidation of $\mathrm{Fe}^{2+}$ to $\mathrm{Fe}^{3+}$. The latter ions form a complex with thiocyanate, which can be detected at $490 \mathrm{~nm}$ using a plate reader following solution separation and transfer to a 96 microplate. Distilled water without sample was used as a negative control, and $\alpha$-tocopherol was used as a positive control. All experiments were performed in triplicate. The inhibition percentages of the lipid peroxidation of linoleic acid were calculated using the following equation:

Inhibition of lipid peroxidation activity $(\%)=\frac{\mathrm{A}_{\text {control }}-\mathrm{A}_{\text {sample }}}{\mathrm{A}_{\text {control }}} \times 100 \%$

Where, $A_{\text {sample }}$ is the absorbance of $\mathrm{NH}_{4} \mathrm{SCN}, \mathrm{FeCl}_{2}$, and linoleic acid with the extract and $A_{\text {control }}$ is the absorbance of $\mathrm{NH}_{4} \mathrm{SCN}, \mathrm{FeCl}_{2}$, and linoleic acid alone. The IPC $\mathrm{IP}_{50}$ value, which is the concentration of the sample that inhibited $50 \%$ of the peroxidation, was determined. A histogram of the inhibition of lipid peroxidation activity (\%) of $0.01 \mathrm{mg} / \mathrm{mL}$ samples following $0,1,2$, and 3 months fermentation is presented.

\section{Chelating ability}

The $\mathrm{Fe}^{2+}$ chelating abilities of the fermented juices were measured using the ferrous iron-ferrozine complex method [26]. Briefly, the reaction mixture containing $2 \mathrm{mM} \mathrm{FeCl}, 10 \mu \mathrm{L}), 5 \mathrm{mM}$ ferrozine $(10 \mu \mathrm{L})$, and five serially diluted concentrations of each sample were mixed in a 24 -well plate and incubated for $10 \mathrm{~min}$ at $25 \pm 2^{\circ} \mathrm{C}$. Subsequently, the solution was separated, transferred to a 96 microplate, and the absorbance was measured at $570 \mathrm{~nm}$ using a plate reader. The absorbance of the control was determined by replacing the samples with ethanol. EDTA $(0.001-10 \mathrm{mg} / \mathrm{mL})$ was used as a positive control. All experiments were performed in triplicate. The $\mathrm{MC}_{50}$ value, which is the concentration of the sample that chelated $50 \%$ of the ferrous iron, was determined. The abilities of the samples to chelate ferrous ions were calculated using the following equation:

$$
\text { Metal chelation activity }(\%)=\frac{\mathrm{A}_{\text {control }}-\mathrm{A}_{\text {sample }}}{\mathrm{A}_{\text {control }}} \times 100 \%
$$

Where, $A_{\text {sample }}$ is the absorbance of $\mathrm{FeCl}_{2}$ and ferrozine with the extract and $A_{\text {control }}$ is the absorbance of $\mathrm{FeCl}_{2}$ and ferrozine alone. A histogram of

Table 1: Scientific name, family, common name, and abbreviation of the six selected medicinal plants for fermentation

\begin{tabular}{lll}
\hline Scientific name & Family & Common name \\
\hline Garcinia mangostana L. & Clusiaceae & Mangosteen \\
Tinospora crispa L. & Menispermaceae & Heartleaf moonseed \\
Litchi chinensis Sonn. & Sapindaceae & Lychee \\
Dimocarpus longan Lour. & Sapindaceae & Longan \\
Curcuma xanthorrhiza Roxb. & Zingiberaceae & LC \\
Averrhoa bilimbi Linn. & Oxalidaceae & DL \\
\hline
\end{tabular}


the metal chelation activity (\%) of $0.01 \mathrm{mg} / \mathrm{mL}$ samples following 0,1 , 2 , and 3 months fermentation is presented.

\section{Tyrosinase inhibition assay}

The fermented juices were assayed using a previously described tyrosinase inhibition method [27], with slight modifications. Briefly, $120 \mu \mathrm{L} 1.66 \mathrm{mM}$ tyrosine solution in $0.1 \mathrm{M}$ phosphate buffer ( $\mathrm{pH}$ 6.8), $60 \mu \mathrm{L}$ five serially diluted concentrations of each sample, and $60 \mu \mathrm{L}$ phosphate buffer were mixed in a 96-well plate and incubated at $37 \pm 2^{\circ} \mathrm{C}$ for $60 \mathrm{~min}$. Subsequently, $60 \mu \mathrm{L}$ tyrosinase enzyme solution $(0.6 \mathrm{mg} /$ $\mathrm{mL}$ ) in phosphate buffer was added. The enzyme activity at $37 \pm 2^{\circ} \mathrm{C}$ was measured at $450 \mathrm{~nm}$ using a plate reader. Kojic acid was used as a positive control. All experiments were performed in triplicate. The $\mathrm{IC}_{50}$ value, which is the concentration of the sample that inhibited $50 \%$ of the enzyme activity, was determined. The inhibition percentages of tyrosinase were calculated using the following equation:

$$
\text { Tyrosinase inhibition activity }(\%)=\frac{A_{\text {control }}-A_{\text {sample }}}{A_{\text {control }}} \times 100 \%
$$

Where, $A_{\text {sample }}$ is the absorbance of tyrosine and tyrosinase with the extract and $A_{\text {control }}$ is the absorbance of tyrosine and tyrosinase alone. A histogram of the tyrosinase inhibition activity (\%) of $0.01 \mathrm{mg} / \mathrm{mL}$ samples following $0,1,2$, and 3 months fermentation is presented.

\section{Cell culture}

Human colon adenocarcinoma (HT-29), cervical cancer (HeLa), hepatocellular carcinoma (HepG2), and murine melanoma (B16F10) cells were cultured under the standard conditions in complete DMEM, and normal human skin fibroblasts were cultured in complete MEMalpha, both supplemented with $10 \%$ (v/v) FBS, penicillin $(100 \mathrm{U} / \mathrm{mL})$, and streptomycin $(100 \mathrm{mg} / \mathrm{mL})$. Cells were incubated in a temperature controlled, humidified incubator (Shel Lab, model 2123TC, USA) with $5 \% \mathrm{CO}_{2}$ at $37^{\circ} \mathrm{C}$.

\section{Cytotoxic activity measured by the SRB assay}

The selected fermented juices at five serially diluted concentrations, the standard anticancer drugs, cisplatin and doxorubicin, and a commercial fermented juice were tested for cytotoxic activity on four cancer cell lines and normal skin fibroblasts using the SRB assay according to the method reported by Papazisis et al. [28]. Briefly, cells were plated at a density of $1.0 \times 10^{4}$ cells/well on 96-well plates and incubated for $24 \mathrm{~h}$ at $5 \% \mathrm{CO}_{2}$ and $37^{\circ} \mathrm{C}$. Cells were subsequently exposed to five serially diluted concentrations of each sample for $24 \mathrm{~h}$. Following incubation, cells were fixed in $50 \%$ TCA solution at $4^{\circ} \mathrm{C}$ for $1 \mathrm{~h}$ and washed 5 times with distilled water. The excess water was drained and the plates were air-dried for $24 \mathrm{~h}$. Cells were subsequently stained with $50 \mu \mathrm{L} 0.4 \%$ SRB solution in $1 \%$ acetic acid for $30 \mathrm{~min}$ at room temperature $\left(25 \pm 2^{\circ} \mathrm{C}\right)$. Following staining, the SRB solution was decanted and the plates were washed with $1 \%$ acetic acid until only the adhered dye remained. The plates were airdried and $100 \mu \mathrm{L} 10 \mathrm{mM}$ tris-base solution was added to solubilize the dye. The plates were shaken for $30 \mathrm{~min}$ at room temperature $\left(25 \pm 2^{\circ} \mathrm{C}\right)$, and the absorbance was measured at $540 \mathrm{~nm}$ using a plate reader. All experiments were performed in triplicate. The percentages of cell viability were calculated using the following equation:

$$
\text { Cell viability }(\%)=\frac{\left(A_{\text {sample }}-A_{\text {blank }}\right)}{\left(A_{\text {control }}-A_{\text {blank }}\right)} \times 100 \%
$$

Where, $A_{\text {sample }}$ is the optical density of the cells treated with the extract, $A_{\text {control }}$ is the optical density of the non-treated cells, and $A_{\text {blank }}$ is the optical density of the tris-base solution at time zero. The $\mathrm{IC}_{50}$ value, which is the concentration that inhibits $50 \%$ of cell viability, was obtained by plotting the percentages of cell viability versus the concentrations of the samples.

\section{Statistical analysis}

The results are presented as the mean \pm standard deviation (SD) of three independent experiments. The data were analyzed using ANOVA with an least SD test; $p<0.05$ is considered statistically significant.

\section{RESULTS AND DISCUSSION}

\section{Antioxidant effect of the fermented juices}

\section{DPPH scavenging activity}

The percentages of DPPH scavenging activity of the fermented juices at $0.01 \mathrm{mg} / \mathrm{mL}$ at time 0 , and following 1,2 , and 3 months fermentation and their $\mathrm{SC}_{50}$ values are shown in Fig. 1 and Table 2. Ascorbic acid (the standard antioxidant) had an $\mathrm{SC}_{50}$ value of $0.025 \mathrm{mg} / \mathrm{mL}$. The fermented juice from CX exhibited a higher DPPH scavenging activity than those of the other plants. The highest

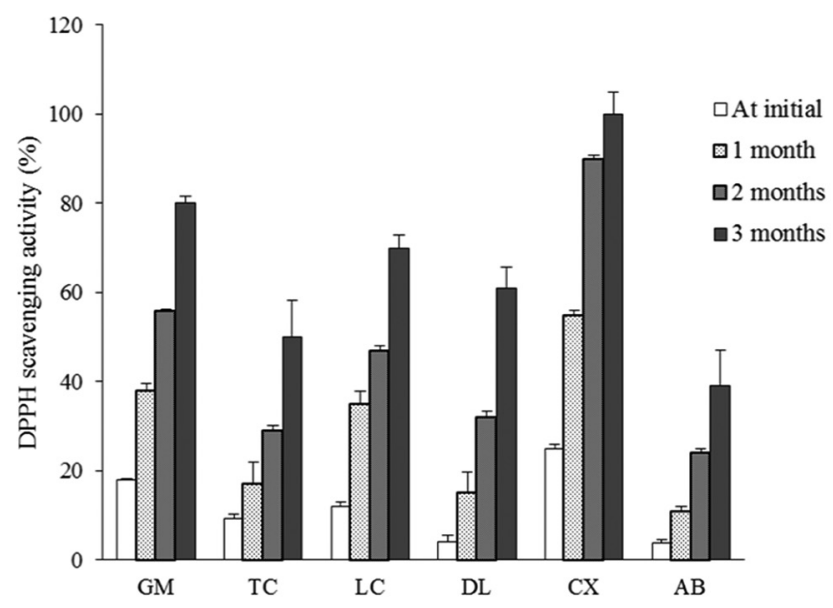

Fig. 1: Comparison of the percentages of DPPH scavenging activity of fermented juices at time 0 , and following 1,2 , and 3 months fermentation

Table 2: DPPH radical scavenging $\left(\mathrm{SC}_{50}\right)$, lipid peroxidation inhibition $\left(\mathrm{IPC}_{50}\right)$, metal chelation $\left(\mathrm{MC}_{50}\right)$, and tyrosinase inhibition (IC $\left.\mathrm{IO}_{50}\right)$ activities of fermented juices at 3 months and reference compounds

\begin{tabular}{llllll}
\hline Scientific name & Abv & $\mathbf{S C}_{50}(\mathbf{m g} / \mathbf{m L})$ & $\mathbf{I P C}_{50}(\mathbf{m g} / \mathbf{m L})$ & $\mathbf{M C}_{50}(\mathbf{m g} / \mathbf{m L})$ & $\mathbf{I C}_{50}(\mathbf{m g} / \mathbf{m L})$ \\
\hline Garcinia mangostana & GM & $0.015 \pm 0.003$ & $0.015 \pm 0.005$ & $\mathrm{n}$ & $0.027 \pm 0.002$ \\
Tinospora crispa & TC & $0.081 \pm 0.012$ & $0.051 \pm 0.001$ & $\mathrm{n}$ & $0.043 \pm 0.001$ \\
Litchi chinensis & LC & $0.029 \pm 0.011$ & $0.015 \pm 0.012$ & $\mathrm{n}$ & $0.008 \pm 0.001$ \\
Dimocarpus longan & DL & $0.046 \pm 0.013$ & $0.078 \pm 0.001$ & $\mathrm{n}$ & $0.041 \pm 0.001$ \\
Curcuma xanthorrhiza & $\mathrm{CX}$ & $0.011 \pm 0.008$ & $0.027 \pm 0.001$ & $0.170 \pm 0.090$ & $0.027 \pm 0.005$ \\
Averrhoa bilimbi & AB & $0.095 \pm 0.009$ & $0.028 \pm 0.001$ & $\mathrm{n}$ & $0.510 \pm 0.065$ \\
Ascorbic acida) & & $0.025 \pm 0.008$ & - & - & - \\
$\alpha$-Tocopherol $^{\text {a) }}$ & & - & $0.0005 \pm 0.0001$ & - & - \\
EDTA $^{\text {a) }}$ & - & - & $0.0002 \pm 0.0001$ & - \\
Kojic acid $^{\text {a) }}$ & & - & - & - & $0.0008 \pm 0.0001$ \\
\hline
\end{tabular}

a): Reference compound, n=No activity, -: Did not detected, DPPH: 2,2-diphenyl-1-picrylhydrazyl radical 


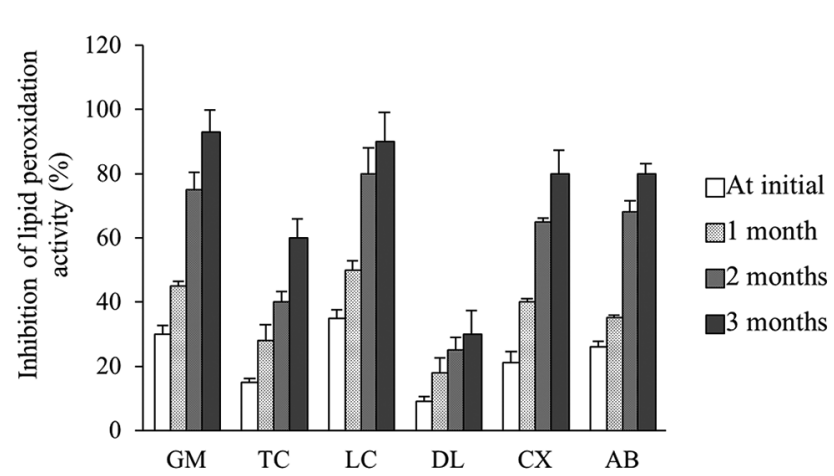

Fig. 2: Comparison of the percentages of lipid peroxidation inhibition activity of fermented juices at $0.01 \mathrm{mg} / \mathrm{mL}$ at time 0 , and following 1, 2, and 3 months fermentation

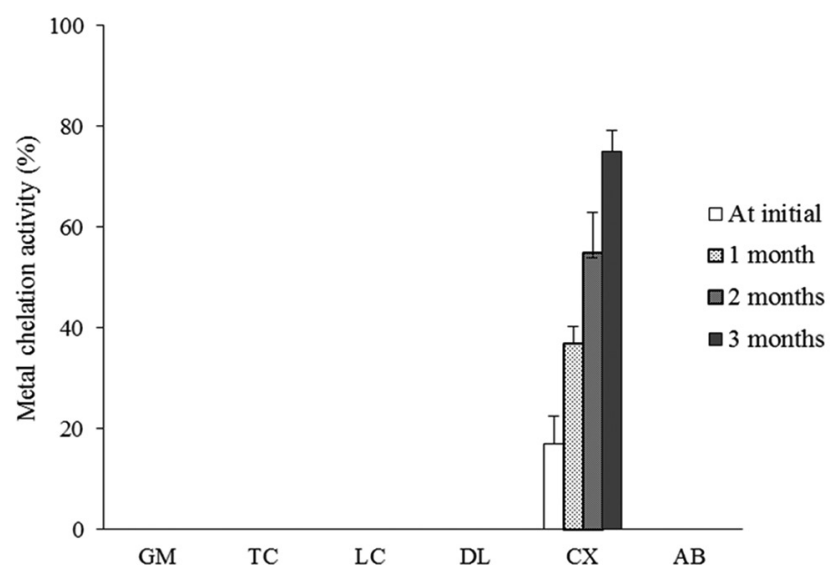

Fig. 3: Comparison of the percentages of metal chelation activity of fermented juices at $0.01 \mathrm{mg} / \mathrm{mL}$ at time 0 , and following 1,2 , and 3 months fermentation

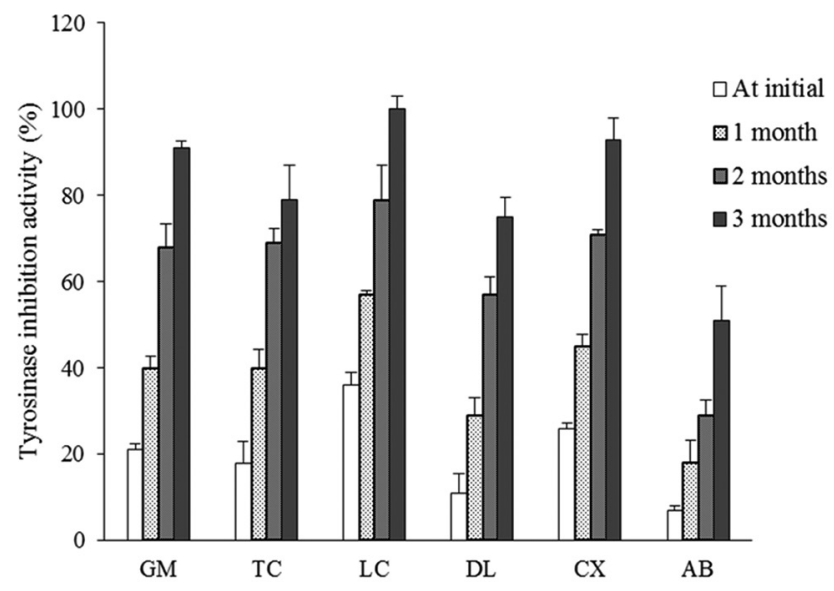

Fig. 4: Comparison of the percentages of tyrosinase inhibition activity of fermented juices at $0.01 \mathrm{mg} / \mathrm{mL}$ at time 0 , and following 1, 2, and 3 months fermentation

scavenging activity, 98.64\%, of CX fermented juice was found at $0.01 \mathrm{mg} / \mathrm{mL}$ and following 3 months fermentation, with an $\mathrm{SC}_{50}$ value of $0.011 \mathrm{mg} / \mathrm{mL}$, which was 2.3 times more potent than ascorbic acid. The DPPH scavenging activity of every fermented juice was increased with increasing fermentation time. The effect of fermentation on the antioxidant properties of various plant materials has been previously investigated, with an increase in phenolic content following fermentation being shown to be responsible for the enhanced antioxidant activity $[29,30]$. Previous studies have indicated that the strong antioxidant activity of the rhizome oil of CX may be related to the high level of xanthorrhizol (32\%); however, there are other relevant constituents present such as curcuminoid, which is the main yellow bioactive substance $[31,32]$. The radical scavenging activity of curcuminoids from the rhizomes of CX has been investigated and confirmed by many researchers [33-35]. The root of $\mathrm{CX}$ also contains a mixture of dicinnamoylmethane derivatives such as curcumin (diferuloylmethane), monodemethoxycurcumin (feruloylp-hydroxycinnamoylmethane), and bisdesmethoxycurcumin (bis-(phydroxycinnamoyl) methane) [36].

\section{Lipid peroxidation inhibition activity}

None of the fermented juices had a greater lipid peroxidation inhibition activity than $\alpha$-tocopherol. At $0.01 \mathrm{mg} / \mathrm{mL}$, standard $\alpha$-tocopherol had an $\mathrm{IPC}_{50}$ value of $0.0005 \mathrm{mg} / \mathrm{mL}$ (Table 2). Among the six plants, GM and LC fermented juices showed the highest peroxidation inhibition activities, with $\mathrm{IPC}_{50}$ values of $0.015 \mathrm{mg} / \mathrm{mL}$, whereas DL fermented juice had the lowest activity, with an $\mathrm{IPC}_{50}$ value of $0.078 \mathrm{mg} / \mathrm{mL}$. The fermented juice of CX had a moderate lipid peroxidation inhibition activity, with an $\mathrm{IPC}_{50}$ value of $0.027 \mathrm{mg} / \mathrm{mL}$ (Table 2 and Fig. 2). Curcumin, which is also one of the components of CX, has been found to inhibit liposomal peroxidation and peroxide-induced DNA damage [37].

\section{Metal chelating activity}

$\mathrm{The} \mathrm{MC}_{50}$ values of the metal chelating activities of the six fermented juices are shown in Table 2. None of the fermented juices except CX showed any chelating activity. The fermented juice of $\mathrm{CX}$ had an $\mathrm{MC}_{50}$ value of $0.170 \mathrm{mg} / \mathrm{mL}$, whereas the standard compound, EDTA, had a value of $0.0002 \mathrm{mg} / \mathrm{mL}$. Fig. 3 shows the comparison of the metal chelating percentages of CX fermented juices at $0.01 \mathrm{mg} / \mathrm{mL}$ at time 0 , and following 1,2 , and 3 months fermentation. The metal chelating activity of CX fermented juice increased with increasing fermentation time. This may be due to the fact that CX contains an enormous amount of polyphenolic compounds [38], which are potent antioxidants as a result of their metal chelating properties [39]. Moreover, the high chelating effect may be due to the ability of xanthorrhizol, the major active compound in $\mathrm{CX}$, to chelate $\mathrm{Cu}^{2+}$ ions and inhibits the initiation of free radical formation [40], which could be attributed to tyrosinase inhibition activity [41].

\section{Tyrosinase inhibition activity}

Fig. 4 and Table 2 show the comparison of the tyrosinase inhibition activities (\%) of the fermented juices at $0.01 \mathrm{mg} / \mathrm{mL}$ at time 0 , and following 1,2 , and 3 months fermentation and the $\mathrm{IC}_{50}$ values of the tyrosinase inhibition activity of the fermented juices at 3 months. The tyrosinase inhibition activity of every fermented juice was increased with increasing fermentation time. The fermented juice of LC showed the highest tyrosinase inhibition activity of $97.47 \%$, with an $\mathrm{IC}_{50}$ value of $0.008 \mathrm{mg} / \mathrm{mL}$ following 3 months fermentation; however, this value was lower than that of Kojic acid, which is a strong tyrosinase enzyme inhibitor. The CX fermented juice showed a tyrosinase inhibition activity of $93.11 \%$, with an $\mathrm{IC}_{50}$ value of $0.027 \mathrm{mg} / \mathrm{mL}$ following 3 months fermentation, which was 3.4 times lower than that of the LC fermented juice. Evaluation of tyrosinase inhibition is the most common approach for the elucidation of skin lightening agents since this enzyme catalyzes the rate-limiting step of pigmentation [42]. Recently, it has been shown that fermented rice extract has an enhanced tyrosinase inhibition activity as compared with the unfermented rice extract. Moreover, fungi are known to have great potential for the production of bioactive compounds which lead to the enhancement of various biological activities in fermented substrates. Fungi produce many enzymes during fermentation, such as glycoside, hydrolase, cellulose, or xylan-degrading enzymes 
Table 3: The cytotoxicity $\left(\mathrm{IC}_{50}\right)$ and cell viability (\%) of the fermented juices, the commercial fermented juice product, and the standard anticancer drugs, cisplatin and doxorubicin, in four cancer cell lines, and normal fibroblast cells, respectively

\begin{tabular}{|c|c|c|c|c|c|c|}
\hline \multirow[t]{2}{*}{ Scientific name } & \multirow[t]{2}{*}{ Abv } & \multicolumn{4}{|c|}{$\mathrm{IC}_{50}(\mathrm{mg} / \mathrm{mL})$} & \multirow[t]{2}{*}{ Cell viability in normal cells (\%) } \\
\hline & & HeLa & HT-29 & HepG2 & $\mathbf{B}_{16} \mathbf{F}_{10}$ & \\
\hline Garcinia mangostana & GM & $736 \pm 11$ & $451 \pm 38$ & $>$ & $655 \pm 41$ & $112.5 \pm 8.4$ \\
\hline Tinospora crispa & TC & $862 \pm 23$ & $>$ & $615 \pm 18$ & $>$ & $39.6 \pm 1.3$ \\
\hline Litchi chinensis & LC & $>$ & $>$ & $>$ & $>$ & $104.3 \pm 11.1$ \\
\hline Dimocarpus longan & DL & $>$ & $>$ & $>$ & $>$ & $68.6 \pm 7.4$ \\
\hline Curcuma xanthorrhiza & $\mathrm{CX}$ & $370 \pm 23$ & $446 \pm 27$ & $386 \pm 8$ & $470 \pm 14$ & $59.6 \pm 3.6$ \\
\hline Averrhoa bilimbi & $\mathrm{AB}$ & $>$ & $>$ & $>$ & $>$ & $110 \pm 9.8$ \\
\hline Commercial fermented juice product & & $>$ & $293 \pm 11$ & $>$ & $>$ & $44.4 \pm 4.6$ \\
\hline Cisplatin $^{\text {a) }}$ & & $0.28 \pm 0.02$ & $0.19 \pm 0.01$ & $26.40 \pm 1.20$ & - & - \\
\hline Doxorubicin $^{\text {a) }}$ & & $7.59 \pm 0.03$ & $8.21 \pm 0.05$ & $0.70 \pm 0.02$ & $8.29 \pm 0.10$ & - \\
\hline
\end{tabular}

a): Reference compound, >: IC50>1000 mg/mL, -: Not detected

and esterase [43], which may suggest enhancement of tyrosinase inhibition activity [44].

\section{Cytotoxic activity in human cancer cell lines}

The cytotoxicity $\left(\mathrm{IC}_{50}\right)$ and cell viability (\%) of the fermented juices, a commercial fermented juice product, and standard anticancer drugs in four cancer cell lines and normal skin fibroblasts, respectively, are shown in Table 3. The fermented juice of CX showed greater cytotoxicity than those of the other fermented juices with $\mathrm{IC}_{50}$ values of $370,446,386$, and $470 \mathrm{mg} / \mathrm{mL}$ in HeLa, HT-29, HepG2, and B16F10, respectively, whereas the fermented juices of LC, DL, and $\mathrm{AB}$ showed no activity in these four cancer cell lines. GM and TC fermented juices showed cytotoxicity in certain cancer cell lines; HeLa (IC ${ }_{50}$ value of $736 \mathrm{mg} / \mathrm{mL}$ ), HT-29 (IC ${ }_{50}$ value of $451 \mathrm{mg} / \mathrm{mL}$ ), and B16F10 (IC ${ }_{50}$ value of $655 \mathrm{mg} / \mathrm{mL}$ ) for $\mathrm{GM}$; and HeLa $\left(\mathrm{IC}_{50}\right.$ value of $862 \mathrm{mg} / \mathrm{mL}$ ) and HepG2 (IC ${ }_{50}$ value of $615 \mathrm{mg} / \mathrm{mL}$ ) for TC. The expensive commercial fermented juice product exhibited cytotoxicity only in HT-29 cells, with an $\mathrm{IC}_{50}$ value of $293 \mathrm{mg} / \mathrm{mL}$, and also showed some toxicity in normal skin fibroblasts, with a cell viability of $44.4 \%$. As expected, the standard anticancer drugs, cisplatin and doxorubicin, showed greater anticancer activity than all fermented juices, with $\mathrm{IC}_{50}$ values in the $\mu \mathrm{g} / \mathrm{mL}$ range (Table 3 ). Xanthorrhizol, a sesquiterpenoid compound isolated from the rhizome of $\mathrm{CX}$, has been reported to possess a variety of biological properties including antibacterial, antifungal, and anticancer activities [45-47]. With respect to anticancer activity, Choi et al. [48] observed that injection of 0.2-1.0 mg xanthorrhizol/ kg bw had an antimetastatic effect in a mouse lung metastasis model. In vitro experiments have shown the induction of apoptosis through the upregulation of Bax and p53 in HeLa and HCT116 human colon cancer cells [49]; thus, the phytochemicals found in CX, especially xanthorrhizol, may be synergistic and responsible for the cytotoxicity of CX fermented juice. Furthermore, the results of the present study show that CX fermented juice had a lower toxicity in normal skin fibroblast cells (59.6\%) and a higher anticancer activity in HeLa, HepG2, and B16F10 cells than the expensive commercial fermented juice product that some Thais drink to prevent cancer. Moreover, CX fermented juice may be preferential to standard potent anticancer drugs that have a higher toxicity in normal cells [50].

\section{CONCLUSION}

The present study demonstrates the in vitro antioxidant and anticancer activities, as well as the toxicity in normal cells, of various fermented plant juices. The fermented juice of CX showed the highest DPPH scavenging activity and relatively high lipid peroxidation inhibition, metal chelating, and tyrosinase inhibition activities as compared with those of other fermented juices. Moreover, the fermented juice of CX exhibited cytotoxicity in four cancer cell lines including HeLa, HT29, HepG2, and B16F10 cells, with low toxicity in normal fibroblast cells. Further assessment of the underlying molecular mechanism of this fermented juice should be carried out for its development as a functional food supplement or anticancer product.

\section{ACKNOWLEDGMENTS}

This research was supported by the 2014 grant funding from the Faculty of Pharmacy, Chiang Mai University.

\section{AUTHOR'S CONTRIBUTION}

1. Study conception and design: Ruksiriwanich and Jantrawut

2. Acquisition of data: Akazawa

3. Analysis and interpretation of data: Ruksiriwanich

4. Drafting of manuscript: Jantrawut

5. Critical revision: Ruksiriwanich

\section{CONFLICTS OF INTEREST}

The authors declare that they have no conflicts of interest.

\section{REFERENCES}

1. Cambell P. Fermented Foods of the World-A Dictionary and Guide. London: Butterworths; 1987.

2. Rolle R, Satin M. Basic requirements for the transfer of fermentation technologies to developing countries. Int $\mathrm{J}$ Food Microbiol 2002;75:181-7.

3. Achi $\mathrm{O}$. The potential for upgrading traditional fermented foods through biotechnology. Afr J Biotechnol 2005;4:375-80.

4. Hui Y. The Handbook of Food and Beverage Fermentation Technology. New York: Taylor \& Francis; 2004.

5. Jimenez A, Borja R, Martin A. A comparative kinetic evaluation of the anaerobic digestion of untreated molasses and molasses previously fermented with Penicillium decumbens in batch reactors. Biochem Eng J 2004;18:121-32.

6. Alvarez-Olmos M, Oberhelman R. Probiotic agents and infectious diseases: A modern perspective on a traditional therapy. Clin Infect Dis 2001;32:1567-76.

7. Rijkers GT, de Vos WM, Brummer RJ, Morelli L, Corthier G, Marteau P. Health benefits and health claims of probiotics: Bridging science and marketing. Br J Nutr 2011;106:1291-6.

8. Mattila-Sandholm T, Myllarinen P, Crittenden R, Mogensen G, Fonden R, Saarela M. Technological challenges for future probiotic foods. Int Dairy J 2002;12:173-82.

9. Garrity AR, Morton JC, Morrison P, De LH, Nutraceutical Mangosteen Tea. Google Patents; 2005.

10. Andayani R, Wahyuni FS, Wirasti Y, Dachriyanus. Development and validation of RP-HPLC method for quantitative estimation of alphamangostin in the rind extract and fractions of Garcinia mangostana $\mathrm{L}$. and their cytotoxic activity on T47D breast cancer cell line. Int J Pharm Pharm Sci 2015;7:174-8.

11. Perry L. Medicinal Plants of East and Southeast Asia: Attributed Properties and Uses. Cambridge: The MIT Press; 1980. p. 620.

12. Amom Z, Azman KF, Ismail NA, Shah ZM, Arshad MS. An aqueous extract of Tinospora cispa possesses antioxidative properties and reduces atherosclerosis in hypercholesterolemic-induced rabbits. J Food Biochem 2011;35:1083-98.

13. Ibahim M, Wan-Nor I'zzah W, Narimah A, Nurul Asyikin Z, Siti-Nur Shafinas S, Froemming G. Anti-proliperative and antioxidant effects of Tinospora crispa (Batawali). Biomed Res 
2011;22:57-62.

14. Kongsaktrakoon B, Temsiririrkkul R, Nakornchai S, Suvitayavat W, Wongkrajang Y. The antipyretic effect of Tinospora crispa Mier ex Hook F. and Thoms. Mahidol J Pharm Sci 1994;21:1-6.

15. Li J, Jiang Y. Litchi flavonoids: Isolation, identification and biological activity. Molecules 2007;12:745-58.

16. Soong YY, Barlow PJ. Antioxidant activity and phenolic content of selected fruit seeds. Food Chem 2004;88:411-7.

17. Wang X, Yuan S, Wang J, Lin P, Liu G, Lu Y, et al. Anticancer activity of litchi fruit pericarp extract against human breast cancer in vitro and in vivo. Toxicol Appl Pharmacol 2006;215:168-78.

18. Zhao M, Yang B, Wang J, Li B, Jiang Y. Identification of the major flavonoids from pericarp tissues of lychee fruit in relation to their antioxidant activities. Food Chem 2006;98:539-44.

19. Jantan I, Saputri FC, Qaisar MN, Buang F. Correlation between chemical composition of Curcuma domestica and Curcuma xanthorrhiza and their antioxidant effect on human low-density lipoprotein oxidation. Evid Based Complement Alternat Med 2012;1:1-10.

20. SukandarEY, Kurniati NF, Anggadiredja K, KamilA. In vitro antibacterial activity of Kaempferia pandurata Roxb. and Curcuma xanthorrhiza Roxb. extracts in combination with certain antibiotics against MSSA and MRSA. Int J Pharm Pharm Sci 2016;8:108-11.

21. Pari L, Saravanan G. Antidiabetic effect of Cogent db, a herbal drug in alloxan-induced diabetes mellitus. Comp Biochem Physiol C Toxicol Pharmacol 2002;131:19-25.

22. Mani K, Kandan K, Ganesan D. Antidiabetic and antihyperlipidemic properties of Phyllanthus emblica Linn.(Euphorbiaceae) on streptozotocin induced diabetic rats. Pak J Nutr 2010;9:43-51.

23. Tachibana Y, Kikuzaki H, Lajis NH, Nakatani N. Antioxidative activity of carbazoles from Murraya koenigii leaves. J Agric Food Chem 2001;49:5589-94.

24. Osawa T, Namiki M. A novel type of antioxidant isolated from leaf wax of Eucalyptus leaves. Agric Biol Chem 1981;45:735-9.

25. Sun Q, Shen H, Luo Y. Antioxidant activity of hydrolysates and peptide fractions derived from porcine hemoglobin. J Food Sci Technol 2011;48:53-60.

26. Decker EA, Welch B. Role of ferritin as a lipid oxidation catalyst in muscle food. J Agric Food Chem 1990;38:674-7.

27. Shimizu K, Kondo R, Sakai K, Lee SH, Sato H. The inhibitory components from Artocarpus incisus on melanin biosynthesis. Planta Med 1998;64:408-12.

28. Papazisis KT, Geromichalos GD, Dimitriadis KA, Kortsaris AH. Optimization of the sulforhodamine B colorimetric assay. J Immunol Methods 1997;208:151-8.

29. Bhanja T, Kumari A, Banerjee R. Enrichment of phenolics and free radical scavenging property of wheat koji prepared with two filamentous fungi. Bioresour Technol 2009;100:2861-6.

30. Lee IH, Hung YH, Chou CC. Solid-state fermentation with fungi to enhance the antioxidative activity, total phenolic and anthocyanin contents of black bean. Int J Food Microbiol 2008;121:150-6.

31. Chainani-Wu N. Safety and anti-inflammatory activity of curcumin: A component of tumeric (Curcuma longa). J Altern Complement Med 2003;9:161-8

32. Duke J. CRC Handbook of Medicinal Spices. Washington DC: CRC Press; 2002.

33. Jayaprakasha GK, Rao LJ, Sakariah KK. Antioxidant activities of curcumin, demethoxycurcumin and bisdemethoxycurcumin. Food Chem 2006;98:720-4.

34. Masuda T, Isobe J, Jitoe A, Nakatani N. Antioxidative curcuminoids from rhizomes of Curcuma xanthorrhiza. Phytochemistry 1992;31:3645-7.

35. Sreejayan N, Rao MN. Free radical scavenging activity of curcuminoids. Arzneimittelforschung 1996;46:169-71.

36. Ruslay S, Abas F, Shaari K, Zainal Z, Sirat H, Israf DA, et al. Characterization of the components present in the active fractions of health gingers (Curcuma xanthorrhiza and Zingiber zerumbet) by HPLC-DAD-ESIMS. Food Chem 2007;104:1183-91.

37. Shalini VK, Srinivas L. Lipid peroxide induced DNA damage: Protection by turmeric (Curcuma longa). Mol Cell Biochem 1987;77:3-10.

38. Ab Halim MR, Tan MS, Sabariah I, Mahmud R. Standardization and phytochemical studies of Curcuma Xanthorrhiza Roxb. Int J Pharm Pharm Sci 2012;4:606-10.

39. Ardestani A, Yazdanparast R. Cyperus rotundus suppresses AGE formation and protein oxidation in a model of fructose-mediated protein glycoxidation. Int J Biol Macromol 2007;41:572-8.

40. Yu LL, Zhou K, Parry JW. Inhibitory effects of wheat bran extracts on human LDL oxidation and free radicals. LWT Food Sci Technol 2005;38:463-70.

41. Batubara I, Julita I, Darusman LK, Muddathir AM, Mitsunaga T. Flower bracts of Temulawak (Curcuma Xanthorrhiza) for skin care: Anti-acne and whitening agents. Procedia Chem 2015;14:216-24.

42. Solano F, Briganti S, Picardo M, Ghanem G. Hypopigmenting agents: An updated review on biological, chemical and clinical aspects. Pigment Cell Res 2006;19:550-71.

43. Cai S, Wang O, Wu W, Zhu S, Zhou F, Ji B, et al. Comparative study of the effects of solid-state fermentation with three filamentous fungi on the total phenolics content (TPC), flavonoids, and antioxidant activities of subfractions from oats (Avena sativa L.). J Agric Food Chem 2011;60:507-13.

44. Jamaluddin A, Rashid NY, Razak DL, Sharifudin SA, Long K. Effect of fungal fermentation on tyrosinase and elastase inhibition activity in rice bran. Agric Agric Sci Procedia 2014;2:252-6.

45. Kwan HJ, Seok SJ, In BN, Ryang PY. Xanthorrhizol: A potential antibacterial agent from Curcuma xanthorrhiza against Streptococcus mutans. Planta Med 2000;66:196-7.

46. Mata R, MartÃnez E, Bye R, Morales G, Singh MP, Janso JE, et al. Biological and mechanistic activities of xanthorrizol and 4-(1', 5'-Dimethylhex-4'-enyl)-2-methylphenol isolated from Iostephane heterophylla. J Nat Prod 2001;64:911-4.

47. Musfiroh I, Muchtaridi M, Muhtadi A, Diantini A, Hasanah AN, Udin LZ, et al. Cytotoxicity studies of xanthorrhizol and its mechanism using molecular docking simulation and pharmacophore modelling. J Appl Pharm Sci 2013;3:7-15.

48. Choi MA, Kim SH, Chung WY, Hwang JK, Park KK. Xanthorrhizol, a natural sesquiterpenoid from Curcuma xanthorrhiza, has an antimetastatic potential in experimental mouse lung metastasis model. Biochem Biophys Res Commun 2004;326:210-7.

49. Kang YJ, Park KK, Chung WY, Hwang JK, Lee SK. Xanthorrhizol, a natural sesquiterpenoid, induces apoptosis and growth arrest in HCT116 human colon cancer cells. J Pharmacol Sci 2009;111:276-84.

50. Lichter AS, Lawrence TS. Recent advances in radiation oncology. N Engl J Med 1995;332:371-9. 